\title{
sciendo
}

Folia Oeconomica Stetinensia

Volume 20 (2020) Issue 1

DOI: $10.2478 /$ foli-2020-0017
WYDZIAL NAUK EKONOMICZNYCH I ZARZĄZZANIA

\section{OUTPUT VOLATILITY AND GOVERNMENT SIZE IN NIGERIA}

Philip I. Nwosa, Ph.D. ${ }^{1}$

Chris Ehinomen, Ph.D. ${ }^{2}$

Ephraim Ugwu, M.Sc. ${ }^{3}$

Department of Economics, Faculty of Social Sciences, Federal University Oye-Ekiti, Nigeria

${ }^{1}$ e-mail: philip.nwosa@fuoye.edu.ng

ORCID: 0000-0001-6073-6659

2 e-mail: christopher.ehinomen@fuoye.edu.ng

ORCID: 0000-0002-5757-8116

3 e-mail: ephraim.ugwu@fuoye.edu.ng

ORCID: 0000-0003-0522-3492

Received 1 October 2019, Accepted 30 March 2020

\begin{abstract}
Research background: Output volatility has potentially adverse consequences on the economy and the stabilizing role of fiscal policy is linked to the share of government size in an economy. Hence, given the relative large share of government in developing countries, government size is expected to play an important role in stabilizing output volatility.

Purpose: This study examines the relationship between output volatility and government size in Nigeria. The study seeks to establish if government size mitigates output volatility in Nigeria.

Research methodology: The study employs the Autoregressive Distributed Lag (ARDL) technique after conducting stationarity and co-integration tests.

Results: The results of the ARDL estimate showed that government size lessens output volatility but the magnitude was insignificant. Further, the study found that volatility in aggregate government spending; international oil price and public debt were significant determinants of output volatility in Nigeria.

Novelty: This showed that the automatic stabilization role of government size on output volatility could not be established. The automatic stabilization role of fiscal policy can be improved by increasing social security transfers (pension payment), payments of unemployment benefits and increasing civil servants minimum wage.
\end{abstract}

Keywords: Output Volatility, Government Size, Auto-regressive distributed lag, Nigeria

JEL classification: E32, E62 


\section{Introduction}

The automatic stabilization role of fiscal policy has remained a contending issue in the literature. From a conceptual perspective, the stabilizing role of fiscal policy is linked to the share of government size in an economy. Government size in any economy has a potentially important role in stabilizing aggregate demand and hence output for two reasons. First, higher government expenditure may be associated with the larger provision of public goods and services as well as a larger fraction of workers employed in the public sector to the extent that government expenditure is more stable than other components of aggregate demand. Consequently government expenditure is expected to reduce volatility in aggregate personal disposable income, aggregate personal consumption and hence reduce volatility in aggregate output (Mohanty, Zampoli, 2009). Secondly, a higher share of government expenditure may also reflect the provision of social security schemes or transfers such as unemployment benefits and state pensions to a large number of citizens. Such transfer reduces volatility in disposable income and helps consumption smoothening which is important for reducing output volatility. Furthermore, tax share could contribute to stabilizing output volatility - a higher tax share among other things remaining equal reduces the volatility of household disposable income and firms' cash flow in the face of fluctuation in their gross income (Mohanty, Zampoli, 2009). On the other hand, higher tax rates reduce the effort to increase the growth rate, hence the growth perspectives decrease.

With respect to empirical literature, there appears to be ambiguity on the relationship between government size and output volatility. A large number of studies seem to suggest a negative relationship between government size and output volatility (see Gali, 1994; Cohen, Follete, 2000; Fatas, Mihov, 2001; Anres, Domenech, Fatas, 2004). These studies concluded that government size acts as an automatic stabilizer in an economy by reducing output volatility. However, P. Van der Noord (2000) and J-T. Guo and S. Harrison (2006) observed a positive relationship between government size and output volatility (that is government size had a destabilising effect on the economy) while M. Mohanty and F. Zampoli (2009) observed no clear evidence on the relationship between government size and output volatility.

The above mentioned empirical literature focused on OECD countries and are crosssectional in nature (Gali, 1994; Fatas, Mihov, 2001; Anres, Domenech, Fatas, 2004; Kim, Lee, 2007) while the only country specific-time-series study was on the US economy (Cohen, Follete, 2000). Literature on this issue appears scanty with respect to Nigeria. Most indigenous or local studies have focused exclusively on the relationship between government spending and 
economic growth (Agu, Okwo, Ugwunta, Idike, 2015; Ogbole, Amadi, Essi, 2011; Nurudeen, Usman, 2010; Oyinlola, 1993). This is particularly worrisome because: One, the share of both government size (government expenditure to real GDP) and aggregate government expenditure have been on the increase as observed in figures 1 and 2. Two, the Nigerian government (public sector) is a key employer of labour and largely responsible for the provision of certain goods and services (such as road construction, medical and education, fire, water, waste management and security services among others). The government is also involved in the payment of pensions to retired civil servants. Hence, given the important role of government, it is therefore pertinent to examine if government size has helped in stabilizing the Nigerian economy by reducing volatility in aggregate output.

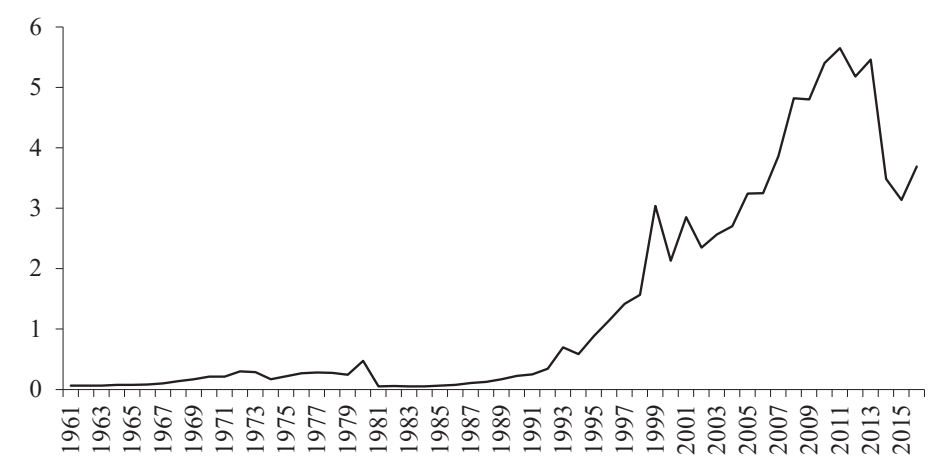

Figure 1. Government Size in Nigeria 1961 to 2017 (\%)

Source: author's own elaboration.

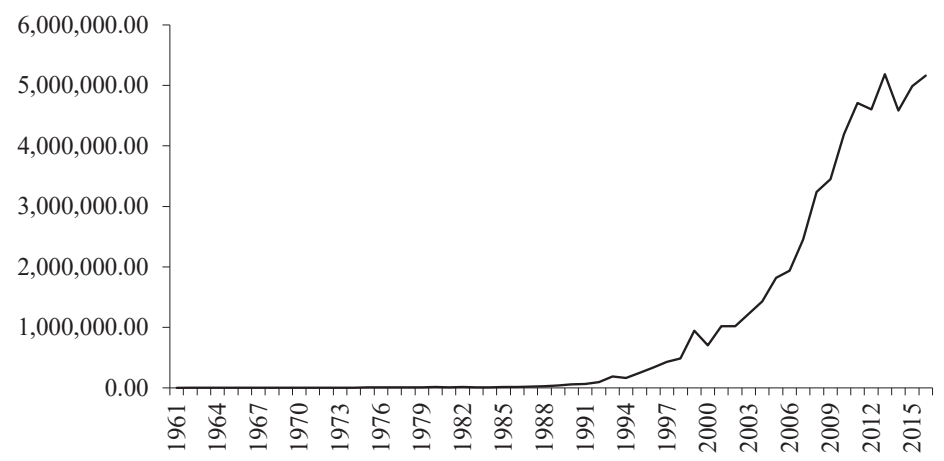

Figure 2: Government Expenditure in Nigeria 1961 to 2017 (A'Billion)

Source: author's own elaboration. 
Drawing from the above, this study seeks to address the following research questions. (i) Is government size a stabilizer of output volatility in Nigeria? (ii) Is government size a key determinant of output volatility in Nigeria? The objective of this study is to examine the relationship between government size and output volatility in Nigeria over the period of 1961 to 2017. The rest of the paper is as follows: section two presents a review of literature on government size and output volatility, section three discusses the research methods while section four discusses the data analysis and results. Section five presents the summary, conclusion and policy recommendation.

\section{Literature Review}

With respect to theoretical literature, classical economists emphasised the absence of government intervention in the belief that government intervention causes instability in the economy and advised that a government should maintain a balanced budget. In contrast, the Keynesian economists emphasised the need for government intervention particularly during recession in order to restore the economy on the path of growth by accelerating aggregate demand. The Ricardian equivalence proposition holds that the impact of fiscal policy (either through tax cuts or government spending) is neutral in the economy in the long run. With respect to empirical literature, D. Xavier, P-F. Jean and S. Andre (2008) investigated the relationship between government size and output volatility for OECD (Organisation for Economic Co-operation and Development) countries. The result of the study suggested that the stabilizing role of fiscal policy seems to have dissipated since the 1990s. According to the study, the breakdown in government size-output volatility relationship largely reflected temporary developments (better monetary management and financial intermediation). Furthermore, the study noted that once monetary management and financial intermediation are taken into account, the stabilizing role of government size remained imperative albeit little extra stability can be gained by expanding public expenditure beyond the threshold level of 40 per cent of GDP.

M. Mohanty and F. Zampoli (2009) examined the relationship between government size and output volatility in twenty (20) selected OECD countries in the period of 1970 to 2008. The study employed the panel ordinary regression technique and the result of the study showed a modest negative relationship between government size and output volatility. Furthermore, the study observed that variables such as volatility of inflation, exposure to terms of trade shocks and trade openness were important determinants of output volatility. K. Erkki and V. Matti (2004) also examined the relationship between government size and output volatility for the 
period 1980 to 1999 . The study covered a group of ninety-one (91) countries and employed the panel regression technique. The result of the study showed that the negative relationship between government size and output volatility among OECD countries could not be generalized to a wider international data set. Also, the result showed a non-linear relationship between government size and output volatility. The negative impact of government size on output volatility was significantly negative only for countries with a high and low public sector.

J. Gali (1994) examined the relationship between government size and output volatility for a group of twenty-two (22) OECD countries in the period of 1960 to 1990. Employing the panel regression technique, the study observed that government size dampens output volatility. Similarly, using cross sectional data for twenty (20) OECD countries, A. Fatas and I. Mihov (2001) observed a negative relationship between government size and output volatility. J-T. Guo and S. Harrison (2006) observed that government size (proxy by income taxes as a ratio of real GDP) had a stabilizing (negative) effect on output volatility while government size (proxy by public spending) had a destabilizing effect on output volatility.

With respect to indigenous literatures, S.U. Agu, I.M. Okwo, O.D. Ugwunta and A. Idike (2015) examined the relationship between fiscal policy and economic growth. Employing the ordinary least squares technique, the study showed evidence of a positive relationship between government expenditure on economic growth. C. Ighodaro and D. Oriakhi (2010), A. Fajingbesi and A. Odusola (1999) and O. Oyinlola (1993) equally observed a positive relationship between fiscal policy and economic growth in Nigeria. Aregbeyen and Kolawole (2015) examined the nexus among oil revenue, government spending and economic growth in Nigeria in the period of 1980 to 2012. The study employed Granger causality and error correction model techniques. The results of the causality estimate showed unidirectional causality from oil revenue to both government expenditure and economic growth while no evidence of causation was observed between government expenditure and economic growth. The error correction model estimates showed that oil revenue had a positive and significant impact on economic growth while an insignificant relationship was observed between government expenditure and economic growth in Nigeria.

J. Ilaboya and E. Ofiafoh (2014) examined the relationship between tax ratio and output volatility in Nigeria in the period of 1980 to 2011. Utilizing the error correction modelling technique, the study found a positive relationship between tax ratio and output volatility. Thus, the study recommends an increase in the revenue base in order to improve the tax revenue to GDP ratio. O. Ogbole, S. Amadi, and I. Essi (2011) examined the relationship between fiscal policy and economic growth in Nigeria in the period of 1970 to 2006 . Specifically, the study 
focused on a comparative analysis of the relationship between fiscal policy and economic growth during regulation and deregulation eras. The findings of the study showed a difference in the relationship between fiscal policy and economic growth in both eras. Also, O. Maku (2009) observed an insignificant relationship between fiscal policy and economic growth in Nigeria.

From the above reviewed literature the following were observed: (i) empirical literature on the relationship between government size and output volatility exists exclusively on OECD countries and the US economy. (b) Results on the government size and output volatility remains inconclusive. (c) There exists a dearth of knowledge on the link between government size and output volatility in Nigeria while studies on the Nigerian economy largely centered on the relationship between government expenditure and economic growth. Thus, this study intends to fill the above gap in literature by carrying out a country specific study on the relationship between government size and output volatility in Nigeria in the period of 1961 to 2017.

\section{Research Method}

\subsection{Theoretical Framework}

The Keynesian theory assumes that the economy is inherently unstable and that output volatility involves significant economic costs. Traditionally, the automatic stabilizing policy reduces the gap between potential output and actual output, reducing the gap implies a reduction in output volatility. Thus, government involvement in the economy would enhance stability due to the proportional link between the magnitude of the impact of an automatic stabilizer and the size of government expenditure (Blinder, Solow, 1974). The central idea of Keynes is that by lessening the impact of liquidity constraints faced by households, government size dampens the impact of exogenous shock to aggregate income, aggregate current consumption and hence output volatility (Xavier, Jean, Andre, 2008).

\subsection{Model Specification}

Based on the theoretical link between the automatic stabilizing role of government size and output volatility, the study specifies the model below.

$$
Y_{t}=f\left(G S_{t}\right)
$$

where $Y_{t}$ is output volatility and $G S_{t}$ is government size. Introducing control variables that is important to the link between output volatility and government size. These variables are classified into two. The first set of control variables are trade openness denoted by $O P X$; GDP 
share of Agricultural output denoted by $A G R$ and crude oil price denoted by $O I L$. These variables have been found to be positively associated with output volatility and government size. Omitting these variables may result in biased estimates (Erkki, Matti, 2004; Persson, Tabellini, 2001; Rodrik, 1998). The second set of control variables are: volatility of government expenditure denoted by $V G P$; ratio of public debt to real GDP denoted by $D B T$ and average consumer price index denoted by CPI. The second set of control variables are potential determinants of output volatility identified in the literature (Xavier, Jean, Andre, 2008; Mohanty, Zampoli, 2009). Volatility in government expenditure may increase output volatility if government spending is unstable. The level of debt may also increase output volatility, for instance, if the government engages in a pro-cyclical fiscal policy (such as a decline in spending or increase in tax) in order to stabilize debt level when output slows. The consumer price index is to capture the stabilization effect of monetary policy (Mohanty, Zampoli, 2009). Including the variables into the model also provide the basis of testing the significance of government size as a determinant of output volatility (Mohanty, Zampoli, 2009); therefore equation (1) gives:

$$
Y_{t}=f\left(G S_{t}, V G P_{t}, O P X_{t}, A G R_{t}, O I L_{t}, D B T_{t}, C P I_{t}\right)
$$

Linearing equation (2) becomes:

$$
\begin{aligned}
Y_{t}=\delta_{0}+\delta_{1} G S_{t} & +\delta_{2} V G P_{t}+\delta_{3} O P X_{t}+\delta_{4} A G R_{t}+\delta_{5} O I L_{t}+ \\
& +\delta_{6} D B T_{t}+\delta_{7} C P I_{t}+\varepsilon_{t}
\end{aligned}
$$

Output volatility (Y) is measure the volatility series of real gross domestic product. Government size (GS) is measured by the ratio of total government expenditure to real GDP, VGP is volatility in government spending, openness (OPX) is measured by the ratio of import plus export to real GDP, AGR is measured by share of agricultural output to real GDP, oil price (OIL) is measured by international crude oil (bonny light) price, debt (DBT) is measured by total public debt to real GDP and CPI is measured by average consumer price index. The data are sourced from the Central Bank of Nigeria statistical bulletin, 2017 edition. Volatility series (such as output (real GDP) and government expenditure (VGP)) are computed using the E-GARCH approach.

\subsection{E-GARCH Model for Volatility Series}

The volatility series for this study are generated using the Exponential Generalize Autoregressive Conditional Heteroeskedaticity (EGARCH) [1,1]. The E-GARCH model is employed due to its capturing of asymmetric effects and its non-imposition of non-negative 
constrain on the parameters (Jamil, Streissler, Kunst, 2012; Kontonikas, 2004). The E-GARCH process is expressed as:

$$
\log \left(\sigma_{t}^{2}\right)=\omega+\log \left(\sigma_{t-1}^{2}\right)+\alpha\left|\frac{\mu_{t-1}}{\sigma_{t-1}}\right|+\gamma\left|\frac{\mu_{t-1}}{\sigma_{t-1}}\right|
$$

Equation (4) describes the conditional variance. The estimates of the conditional variance for the series (that is, output (Y) and government expenditure) are used in equations (3) (Nwosa, Omolade, 2017; Demachi, 2012).

\subsection{ADF and PP Stationarity Test Model Specification}

The ADF test tests the null hypothesis that a time series $y_{t}$ is I(1) against the alternative that it is $\mathrm{I}(0)$, assuming that the dynamics in the data have an Autoregressive Moving Average (ARMA) structure. The ADF test is based on estimating the test regression

$$
y_{t}=\beta^{\prime} D_{t}+\varphi y_{t-1}+\sum_{j=1}^{p} \psi_{j} \Delta y_{t-j}+\varepsilon_{t}
$$

where $D_{t}$ is a vector of the deterministic terms (constant, trend etc.). The $p$ lagged difference terms, $\Delta y_{t-j}$, are used to approximate the ARMA structure of the errors, and the value of $p$ is set so that the error $\varepsilon_{t}$ is serially uncorrelated and also assumed to be homoskedastic (Dickey, Fuller, 1981).

The Phillips-Perron (PP) unit root tests differ from the ADF tests mainly in how the PP test deals with the serial correlation and heteroskedasticity in the errors. In particular, where the ADF tests use a parametric auto-regression to approximate the ARMA structure of the errors in the test regression, the PP tests ignore any serial correlation in the test regression. The test regression for the PP tests is

$$
\Delta y_{t}=\beta^{\prime} D_{t}+\pi y_{t-1}+\sum_{j=1}^{p} \psi_{j} \Delta y_{t-j}+u_{t}
$$

where $u_{t}$ is $\mathrm{I}(0)$ and may be heteroskedastic. The PP tests correct for any serial correlation and heteroskedasticity in the errors $u_{t}$ of the test regress by directly modifying the test statistics $t_{\pi=0}$ and $T \hat{\pi}$. these modified statistics denoted by $Z_{t}$ and $Z_{\pi}$, are given by

$$
Z_{t}=\left(\frac{\hat{\sigma}^{2}}{\hat{\lambda}^{2}}\right)^{1 / 2} \cdot t_{\pi=0}-\frac{1}{2}\left(\frac{\hat{\lambda}^{2}-\hat{\sigma}^{2}}{\hat{\lambda}^{2}}\right) \cdot\left(\frac{T \cdot S E(\hat{\pi})}{\hat{\sigma}^{2}}\right)
$$




$$
Z_{\pi}=T \hat{\pi}-\frac{1}{2} \frac{T^{2} \cdot S E(\hat{\pi})}{\hat{\sigma}^{2}}\left(\hat{\lambda}^{2}-\hat{\sigma}^{2}\right)
$$

Under the null hypothesis that $\pi=0$, the PP $Z_{t}$ and $Z_{\pi}$ statistics have the same asymptotic distributions as the ADF t-statistic and normalized bias statistics. One advantage of the PP tests over the ADF tests is that the PP tests are robust to general forms of heteroskedasticity in the error term $u_{t}$. Another advantage is that the user does not have to specify a lag length for the test regression (Phillips, Perron, 1988).

\section{Result and Discussion}

The results of the Augmented Dickey Fuller (ADF) and Phillips-Perron (PP) tests presented in table 1 showed a mix result of the stationarity status of the variables. Some of the variables were stationary at first difference indicating that the variables were integrated of order one while other variables such as volatility in government spending (VGP), share of agricultural output in real GDP (AGR) and consumer price index (CPI) were stationary at level, indicating that the variables were a $\mathrm{I}(0)$ series.

Table 1. Unit Root Test

\begin{tabular}{|c|c|c|c|c|c|c|}
\hline \multicolumn{4}{|c|}{ Augmented Dickey Fuller (ADF) Test } & \multicolumn{3}{c|}{ Phillips-Perron (PP) Test } \\
\hline variables & level & $\begin{array}{c}\text { after } \\
\text { differencing }\end{array}$ & status & level & $\begin{array}{c}\text { after } \\
\text { differencing }\end{array}$ & status \\
\hline Y & -1.7388 & $-11.6881^{*}$ & $\mathrm{I}(1)$ & -1.5115 & $-5.0677^{*}$ & $\mathrm{I}(1)$ \\
\hline GS & 2.5769 & $-2.8384^{* * *}$ & $\mathrm{I}(1)$ & -2.0013 & $-10.5800^{*}$ & $\mathrm{I}(1)$ \\
\hline VGP & $-8.4592 *$ & - & $\mathrm{I}(0)$ & $-5.3637 *$ & - & $\mathrm{I}(0)$ \\
\hline OPX & -2.2945 & $-8.4467^{*}$ & $\mathrm{I}(1)$ & -2.2937 & $-8.0159^{*}$ & $\mathrm{I}(1)$ \\
\hline AGR & $-3.1385^{* *}$ & - & $\mathrm{I}(0)$ & $-3.1205^{* *}$ & - & $\mathrm{I}(0)$ \\
\hline OIL & -1.8308 & $-9.5773^{*}$ & $\mathrm{I}(1)$ & -1.8308 & $-9.5144^{*}$ & $\mathrm{I}(1)$ \\
\hline DBT & -1.6809 & $-6.1710^{*}$ & $\mathrm{I}(1)$ & -2.4229 & $-6.4085^{*}$ & $\mathrm{I}(1)$ \\
\hline CPI & $-3.6204 *$ & - & $\mathrm{I}(0)$ & $-3.6804^{*}$ & & - \\
\hline
\end{tabular}

Note: $* * *$ and $* *$ denote $1 \%, 5 \%$ and $10 \%$ critical values respectively.

Source: authors' computation 2019 using E-views 9, 2019.

Sequel to the mix in the unit root results, the co-integration test and the regression estimate were carried out using the Auto-Regressive Distributed Lag (ARDL) Bound Co-integration technique. Unlike the Johansen co-integration technique which requires that the variables 
must be integrated of order one, the ARDL co-integration approach is applicable irrespective of whether the variables in the estimating model are purely $\mathrm{I}(0)$, purely $\mathrm{I}(1)$ ) or mutually integrated (Oteng-Abayie, Frimpong, 2006).

Table 2. ARDL Bound Co-integration Test

\begin{tabular}{|c|c|c|}
\hline Estimated Model & \multicolumn{2}{|c|}{ F-Statistics } \\
\hline Estimated Model & \multicolumn{2}{|c|}{5.7641} \\
\hline Critical Values & Lower Bound & Upper Bound \\
\hline $1 \%$ & 3.15 & 4.43 \\
\hline $5 \%$ & 2.45 & 3.61 \\
\hline $10 \%$ & 2.12 & 3.23 \\
\hline
\end{tabular}

Source: authors' computation, using E-views 9, 2019.

The result of the co-integration estimate showed that the value of the F-statistics (5.76) is higher than the value of the upper bound at all levels of the critical value, suggesting the presence of co-integration among the variables in equation (3).

Table 3. ARDL Regression Estimate

\begin{tabular}{|c|c|c|c|}
\hline Regressors & $\begin{array}{c}\text { Estimated } \\
\text { Co-efficient }\end{array}$ & Standard Error & $\mathrm{t}$-Statistics \\
\hline VGP & -0.4403 & 0.1171 & $-3.7604 *$ \\
\hline OIL & 0.0459 & 0.0122 & $3.7629 *$ \\
\hline DBT & 1.3198 & 0.6284 & $2.1002 * *$ \\
\hline $\mathrm{C}$ & 43.0518 & 5.2859 & $8.1446^{*}$ \\
\hline ECM-term & -0.4958 & 0.1011 & $-4.9025^{*}$ \\
\hline \multicolumn{4}{|c|}{$\begin{array}{l}\text { R-Square }=0.935 \\
\text { Adjusted R-Square }=0.899 \\
\text { F-Stat. }(\text { Prob. })=26.34(\mathrm{p}<0.05) \\
\text { Durbin-Watson Stat }=2.03\end{array}$} \\
\hline
\end{tabular}

$*$ and $* *$ denote $1 \%$ and $5 \%$ critical values respectively.

Source: authors' computation using E-views 9, 2019.

From the ARDL regression estimate reported in Table 3 (see full estimate in the appendix), it was observed that volatility in government expenditure (VGP) had a negative but significant impact on output volatility while international oil price (OIL) and debt (DBT) had a positive and significant impact on output volatility in Nigeria. All other variables including government size had an insignificant impact on output volatility. With respect to objective two, the regression estimate showed that volatility in government spending and international oil price were the 
significant determinants of output volatility in Nigeria. In the case of oil price, the Nigerian economy is oil driven and movements in international oil price shapes the behaviour of aggregate output. Periods of high oil prices have usually been synonymous with periods of impressive real GDP growth and vice-versa. The positive link between international oil price and output volatility further implies that international oil price contributes to output volatility in Nigeria. In contrast to a priori expectation, volatility in government spending reducing output volatility in Nigeria. The evidence could reflect discretionary or counter-cyclical fiscal policy whereby the government increases spending during a recession and cut-back spending during periods of impressive economic growth. The importance of the volatility in government spending and international oil price as significant determinants of output volatility is supported by the regression estimate which focused only on the significant variables in Table 3 (see Table A2 in appendix).

The error correction term (ECM-term) from the short run ARDL estimate is expected to be negatively signed and statistically significant. From the estimate, the coefficient of the error correction term was correctly-negatively signed $(-0.496)$ and is statistically significant. The coefficient estimate of the error correction term of -0.496 implied that the model corrects its short-run disequilibrium by about 0.50 per cent speed of adjustment in order to return to the long-run equilibrium.

To evaluate the robustness of the regression estimate, some diagnostic tests were carried out and the results are presented in Table 4. From the table, both the serial correlation LM and heteroskedaticity ARCH estimates showed the absence of serial correlation in the ARDL estimates. This is because the null hypothesis of both tests were accepted as their probability values were greater than 0.05 . The results are also supported by the estimate of the DurbinWatson of 2.03, indications the absence of serial autocorrelation in the regression estimate.

Table 4. Diagnostic Tests

\begin{tabular}{|ll|ll|}
\hline \multicolumn{4}{|c|}{ Breusch-Godfrey Serial Correlation LM Test } \\
\hline F-statistic & 0.1793 & Prob. F(2,31) & 0.8368 \\
\hline Obs*R-squared & 0.5945 & Prob. Chi-Square(2) & 0.7429 \\
\hline \multicolumn{4}{|c|}{ Heteroskedaticity ARCH Test } \\
\hline F-statistic & Prob. F(1,49) & 0.6044 \\
\hline Obs*R-squared & 0.2719 & Prob. Chi-Square(1) & 0.5957 \\
\hline
\end{tabular}

Source: authors' computation, 2019. 


\section{Conclusions}

This study explores the relationship between government size and output volatility in Nigeria from 1961 to 2017. Specifically, the study seeks to establish if government size acts an automatic stabilizer of output volatility as documented in some literature. The study employed the Autoregressive Distributed Lag (ARDL) technique after conducting the stationarity and co-integration tests. The result of the ARDL estimate revealed a negative but insignificant relationship between government size and output volatility in Nigeria. Further, it was observed that volatility in government spending and international oil price were the significant determinants of output volatility in Nigeria. In conclusion, the automatic stabilization role of government size on output volatility could not be established. Sequel to the findings, the study recommends that the automatic stabilization role of fiscal policy can be improved upon by increasing social security transfers (pension payment) and the payments of unemployment benefits. Also, there is the need for the government to reduce its overall reliance on oil due to the destabilizing impact on output volatility. This can be achieved by expanding the revenue base of the government through appropriate economic and revenue diversifications strategies. 


\section{Appendix}

Table A1. Full ARDL Regression Estimate

\begin{tabular}{|l|c|c|c|}
\hline \multicolumn{1}{|c|}{ Regressors } & $\begin{array}{c}\text { Estimated } \\
\text { Co-efficient }\end{array}$ & Standard Error & t-Statistics \\
\hline GS & -0.7927 & 0.8321 & -0.9528 \\
\hline VGP & -0.4403 & 0.1171 & $-3.7604^{*}$ \\
\hline OPX & 0.8545 & 0.7363 & 1.1604 \\
\hline AGR & 0.8960 & 0.5345 & 3.6763 \\
\hline OIL & 0.0459 & 0.0122 & $2.1002 * *$ \\
\hline DBT & 1.3198 & 0.6284 & -0.9519 \\
\hline CPI & -0.0126 & 0.0133 & $8.1446^{*}$ \\
\hline C & 43.0518 & 5.2859 & $-4.9025^{*}$ \\
\hline ECM-term & -0.4958 & 0.1011 & \\
\hline $\begin{array}{l}\text { R-Square }=0.935 \\
\text { Adjusted R-Square }=0.899\end{array}$ & & \\
F-Stat. (Prob.) $=26.34(\mathrm{p}<0.05)$ \\
Durbin-Watson Stat $=2.03$
\end{tabular}

* and $* *$ denote $1 \%$ and $5 \%$ critical values respectively.

Source: authors' computation using E-views 9, 2019.

Table A2. ARDL Regression Estimate with Significant Variable Only

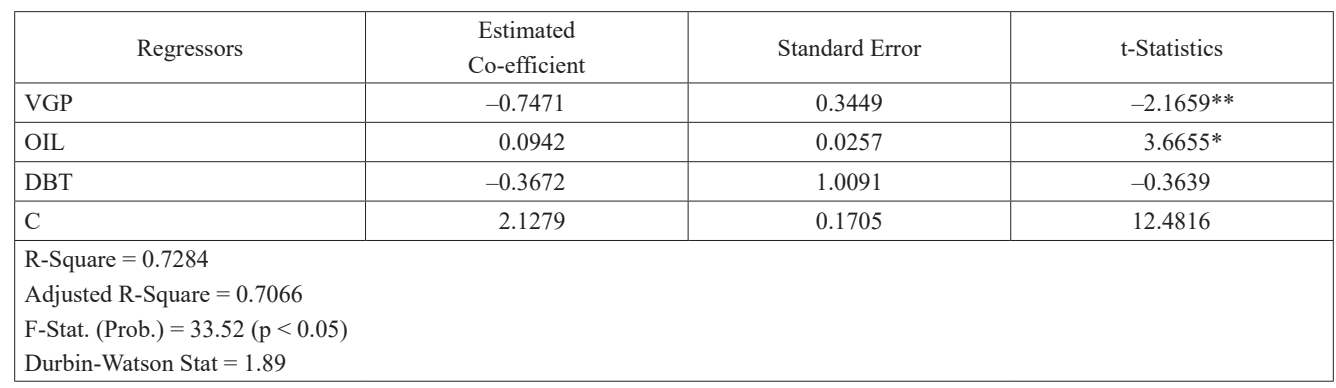

* and ** denote $1 \%$ and $5 \%$ critical values respectively.

Source: authors' computation using E-views 9, 2019. 
Table A3. Estimate of the E-GARCH Model for Output (Y)

\begin{tabular}{|c|c|c|c|c|}
\hline Variable & $\begin{array}{c}\text { Estimated } \\
\text { Co-efficient }\end{array}$ & Standard Error & z-Statistics & Prob. \\
\hline $\mathrm{C}$ & 1.048346 & 0.453627 & 2.311030 & 0.0208 \\
\hline $\mathrm{LY}(-1)$ & 0.943072 & 0.025298 & 37.279020 & 0.0000 \\
\hline \multicolumn{5}{|c|}{ Variance Equation } \\
\hline $\mathrm{C}(3)$ & -1.137932 & 0.453059 & -2.511661 & 0.0120 \\
\hline $\mathrm{C}(4)$ & 1.346771 & 0.882212 & 1.526585 & 0.1269 \\
\hline $\mathrm{C}(5)$ & -1.260672 & 0.857734 & -1.469772 & 0.1416 \\
\hline $\mathrm{C}(6)$ & 0.877035 & 0.070453 & 12.448450 & 0.0000 \\
\hline \multicolumn{5}{|c|}{ R-Squared $=0.956931$} \\
\hline \multicolumn{5}{|c|}{ Adjusted R-Squared $=0.956119$} \\
\hline \multicolumn{5}{|c|}{ S.E. of regression $=0.842588$} \\
\hline \multicolumn{5}{|c|}{ Akaike info criterion $=0.349955$} \\
\hline \multicolumn{5}{|c|}{ Schwarz criterion $=0.568937$} \\
\hline \multicolumn{5}{|c|}{ Hannan-Quinn criterion $=0.434637$} \\
\hline \multicolumn{5}{|c|}{ Durbin-Watson Stat $=1.953923$} \\
\hline
\end{tabular}

Source: authors' computation using E-views 9, 2019.

Table A4. Estimate of the E-GARCH Model for Government Spending (GP)

\begin{tabular}{|c|c|c|c|c|}
\hline Variable & $\begin{array}{c}\text { Estimated } \\
\text { Co-efficient }\end{array}$ & Standard Error & z-Statistics & Prob. \\
\hline $\mathrm{C}$ & 0.265938 & 0.095378 & 2.788242 & 0.0053 \\
\hline $\operatorname{LGP}(-1)$ & 0.995258 & 0.008207 & 121.264900 & 0.0000 \\
\hline \multicolumn{5}{|c|}{ Variance Equation } \\
\hline $\mathrm{C}(3)$ & -4.351351 & 1.671930 & -2.602592 & 0.0093 \\
\hline $\mathrm{C}(4)$ & 0.685588 & 0.728784 & 0.940728 & 0.3468 \\
\hline $\mathrm{C}(5)$ & 0.209610 & 0.302216 & 0.693576 & 0.4879 \\
\hline$C(6)$ & -0.250024 & 0.577845 & -0.432684 & 0.6652 \\
\hline \multicolumn{5}{|c|}{ R-Squared $=0.995005$} \\
\hline \multicolumn{5}{|c|}{ Adjusted R-Squared $=0.994911$} \\
\hline \multicolumn{5}{|c|}{ S.E. of regression $=0.241172$} \\
\hline \multicolumn{5}{|c|}{ Akaike info criterion $=0.011095$} \\
\hline \multicolumn{5}{|c|}{ Schwarz criterion $=0.230077$} \\
\hline \multicolumn{5}{|c|}{ Hannan-Quinn criterion $=0.095777$} \\
\hline \multicolumn{5}{|c|}{ Durbin-Watson Stat $=2.147694$} \\
\hline
\end{tabular}

Source: authors' computation using E-views 9, 2019. 


\section{References}

Agu, S.U., Okwo, I.M., Ugwunta, O.D., Idike, A. (2015). Fiscal policy and economic growth in Nigeria: Emphasis on various components of public expenditure. SAGE Open, OctoberDecember 1-12.

Andres, J., Domenech, R., Fatás A. (2008). The stabilising role of government size, Journal of Economic Dynamics and Control, 32, 571-593.

Aregbeyen, O., Kolawole, B. (2015). Oil revenue, public spending and economic growth relationships in Nigeria. Journal of Sustainable Development, 8 (3), 113-123.

Cohen, D., Follette, G. (2000). The automatic fiscal stabilizers: Quietly doing their thing. Federal Reserve Bank of New York Economic Policy Review April, 35-68.

Demachi, K. (2012). The effect of crude oil price change and volatility on the Nigeria economy. MPRA Paper 41143.

Dickey, D., Fuller, W. (1981). Likelihood ratio statistics for autoregressive time series with a unit root. Econometrica, 49, 1057-1072.

Erkki, K., Matti, V. (2004). Government size and output volatility: New International Evidence. Government institute of economic research, Helsinki, Finland.

Fajingbesi, A., Odusola A. (1999). Public expenditure and growth. A paper presented at a training programme on fiscal policy planning management in Nigeria, organized by NCEMA, Ibadan, Oyo State, 137-179.

Fatas, A., Mihov, I. (2001). Government size and automatic stabilisers: International and intranational evidence. Journal of International Economics, 55, 3-28.

Gali, J. (1994). Government size and macroeconomic stability. European Economic Review, 38, 117-132.

Guo, J-T., Harrison, S. (2006). Government size and macroeconomic stability: A comment. European Economic Review, 50 (5), 1339-1346.

Ighodaro, C., Oriakhi, D. (2010). Does the relationship between government expenditure and economic growth follow Wagner's Law in Nigeria? Annals of the University of Petrosani, Economics, 10 (2), 185-198.

Ilaboya, J., Ofiafoh, E. (2014). Tax ratio and output volatility: Linear time series evidence from Nigeria. Journal of Business Studies Quarterly, 3 (4), 245-267.

Jamil, M., Streissler, E., Kunst, R. (2012). Exchange rate volatility and its impact on industrial production, before and after the introduction of common currency in Europe. International Journal of Economics and Financial Issues, 2 (2), 85-109. 
Kim, D., Lee, C-I. (2007). Government size and inter-sectoral income fluctuations: An international panel analysis. Working paper WP/07/93, International Monetary Fund, Washington, D.C.

Kontonikas, A. (2004). Inflation and inflation uncertainty in the United Kingdom: Evidence from GARCH modelling. Economic Modelling, 21 (3), 525-543.

Maku, O. (2009). Does government spending spur economic growth in Nigeria? MPRA Paper, 17941.

Mohanty, M., Zampoli, F. (2009). Government size and macroeconomic stability, BIS Quarterly Review, December, 55-68.

Nurudeen, A., Usman A. (2010). Government expenditure and economic growth in Nigeria, 1970-2008: A disaggregated analysis. Business and Economic Journal, BEJ-4. Retrieved from: http://astonjournals.com/manuscripts/Vol2010/BEJ-4_Vol2010.pdf.

Nwosa, P., Omolade, A. (2017). Determinants of fdi and fpi volatility: An E-GARCH approach. CBN Journal of Applied Statistics, 8 (2), 47-67.

Ogbole, O., Amadi, S., Essi, I. (2011). Fiscal policy: Its impact on economic growth in Nigeria (1970-2006). Journal of Economics and International Finance, 3, 407-417.

Oteng-Abayie, E., Frimpong, J. (2006). Bounds testing approach to co-integration: An examination of foreign direct investment, trade and growth relationships. American Journal of Applied Sciences, 3 (11), 2079-2085.

Oyinlola, O. (1993). Nigeria's national defence and economic development: An impact analysis. Scandinavian Journal of Development Alternatives, 12 (3), 241-253.

Persson, T., Tabellini, G. (2001). Political institution and policy outcomes: What are the stylised facts? Mimeo, February.

Phillips, P.C.B., Perron, P. (1988). Testing for unit roots in time series regression. Biometrika, $75,335-346$.

Rodrik, D. (1998). Why do more open economics have bigger governments? Journal of Political Economy, 106 (5), 997-1032.

Van der Noord, P. (2000). The size and role of automatic stabilization in the 1990s and beyond. Economics Department Working Paper, 230.

Xavier, D., Jean, P-F., Andre, S. (2008). Government size and output volatility: Should we forsake automatic stabilization? IMF Working Paper, WP/08/122. 